
em design

\title{
0 processo de trabalho do designer: 0 caso dos profissionais João Carlos Cauduro e Ludovico Martino
} The designer's work process: The case of professionals João Carlos Cauduro and Ludovico Martino

\section{fauusp

TEMIN, W. R.

Graduada em Desenho Industrial pela FAAP (1987)

e Mestrado em Design e Arquitetura pela FAU USP

(1999). Atualmente cursa o Doutorado em Design na FAUUSP (2018).

Graduated in Industrial Design from FAAP (1987) and Master's degree in Design and Architecture from FAU USP (1999). She is currently doing a Doctorate in Design at FAUUSP (2018).

\section{BERTOLDI, C. A.}

Professora Doutora nos cursos de Arquitetura e Urbanismo e Design da Universidade de São Paulo. É artista e suas recentes pesquisas englobam estudos sobre criatividade: processo criativo; modelos e protótipos; métodos e raciocínio em projeto. Professor of Architecture and Urbanism and Design at the University of São Paulo. She is an artist and her recent researches include studies on creativity; creative process; models and prototypes; methods and reasoning in design.
0 processo de trabalho do designer é único e fonte de referência para outras áreas do conhecimento. A análise do método de trabalho de designers estabelecidos em uma sociedade uniprofissional, onde exerceram a prática do design juntos por 50 anos pode trazer novas maneiras de pensar o processo projetual. A tese tem como objeto de estudo o processo e a prática de trabalho dos ex-professores da FAUUSP João Carlos Cauduro e Ludovico Antonio Martino que, juntos, formaram o escritório Cauduro/Martino. A pesquisa tem como objetivo identificar os elementos e as suas interrelações no dia a dia dos designers que trabalharam em conjunto, em um determinado espaço de tempo, dos quais se possa depreender o seu processo de trabalho. Processo que por sua vez possa ser traduzido em uma narrativa escrita e gráfica.

Palavras-chave: Processo projetual; História do design; Cauduro/Martino
The designer's work process is both unique and a source of reference for other areas of knowledge. The analysis of the working method of designers established in a professional society where they practiced design together for 50 years can bring new ways of thinking the design process. The thesis aims to study the process and practice of the work of former FAUUSP teachers João Carlos Cauduro and Ludovico Antonio Martino, who together founded the Cauduro / Martino. The research aims to identify the elements and their interrelations in the day-by-day of the designers that worked together in a certain space of time, from which one can understand their work process; a process that can be translated into a written and graphic narrative.

Keywords: Design process; Design history; Cauduro /Martino contato

wilmadareadg.com

craunausp.br

\section{lattes}

http://lattes.cnpq.br/ realização

ppgdesign_fauusp
5 dezembro 2018

cidade universitária, são paulo, sp 